Research Article

\title{
Antiretroviral therapy outcome in human immuno-deficiency virus infected patients in a tertiary care hospital
}

\author{
Hasitha Diana Manohar ${ }^{1}$, Smita Shenoy ${ }^{2}$, Muralidhar Varma ${ }^{3}$, Asha Kamath ${ }^{4}$, \\ Chaithanya Malalur ${ }^{2}$, Kurady Laxminarayana Bairy ${ }^{2}$, Amod Tilak ${ }^{2}$, Kavitha Saravu ${ }^{3}$
}

${ }^{1}$ Department of Pharmacology, Karpaga Vinayaga Institute of Medical Sciences and Research, Dr. M.G.R. University, Kancheepuram,Tamil Nadu, India,

${ }^{2}$ Department of Pharmacology, Kasturba Medical College, Manipal, Manipal University, Karnataka, India,

${ }^{3}$ Department of Medicine, Kasturba Medical College, Manipal, Manipal University, Karnataka, India,

${ }^{4}$ Department of Community Medicine, Kasturba Medical College, Manipal, Manipal University, Karnataka, India

Received: 10 May 2016 Accepted: 18 May 2016

*Correspondence to: Dr. Hasitha Manohar, Email: hasitha1cukoo @ gmail.com

Copyright: (C) the author(s), publisher and licensee Medip Academy. This is an openaccess article distributed under the terms of the Creative Commons Attribution NonCommercial License, which permits unrestricted noncommercial use, distribution, and reproduction in any medium, provided the original work is properly cited.

\begin{abstract}
Background: Human immunodeficiency virus (HIV) presently accounts for the highest number of deaths due to any infective agent in the world. The present study assessed the one year treatment outcome following antiretroviral therapy in HIV positive, treatment naïve patients in a tertiary care hospital.

Methods: Adult HIV positive, antiretroviral treatment naive patients who were started on antiretroviral therapy (ART) between $1^{\text {st }}$ January 2011 and $31^{\text {st }}$ May 2013 were included in the study. Data was collected from their case records. CD4+cell count, haemoglobin level, weight, occurrence of opportunistic infections (OIs) and adverse drug reactions (ADRs) were analysed at baseline, 6 and 12 months following start of antiretroviral therapy. Data was analysed using parametric and nonparametric tests.

Results: Data of 325 patients was analysed. Overall, the median increase in $\mathrm{CD}_{4}{ }^{+}$count at 1 year after initiation of treatment was observed to be clinically significant. Patients on tenofovir based regimen showed a significantly greater increase in the median $\mathrm{CD}_{4}^{+}$count $\left(\mathrm{P}=1.12 \times 10^{-05}\right)$ and haemoglobin $(\mathrm{P}=$ 0.002 ) as compared to those on non-tenofovir based regimen. A total of 151 ADRs were recorded in the study, of which the most common were skin rash $24 \%$, anaemia and gastrointestinal side effects $17 \%$ each. Frequency of opportunistic infections gradually declined after ART. At the end of 1 year of treatment, the cumulative loss to follow up was $7.4 \%$.

Conclusions: By following the current national guidelines, the desired immunological and clinical response following initiation of ART can be achieved while minimizing drug toxicity.
\end{abstract}

Keywords: Antiretroviral therapy, Clinical outcome, Tenofovir, Nontenofovir 


\section{INTRODUCTION}

Human immunodeficiency virus (HIV) currently accounts for the highest number of deaths due to any single infective agent in the world. As per data in March 2013, there are 18.13 lakh people living with HIV/AIDS in India with around 1.16 lakh new HIV infections among adults every year. ${ }^{1}$

As per NACO 2013 guidelines, all HIV infected patients with a $\mathrm{CD}_{4}^{+}$count of $\leq 350$ cells $/ \mathrm{mm}^{3}$ or those with WHO clinical stage 3 or 4 irrespective of $\mathrm{CD}_{4}^{+}$count should be initiated on ART. ${ }^{1}$ The regimen selected is based on their efficacy, side effects, drug availability, cost, potential drug interactions, comorbidities, opportunistic infections (OIs), and need for laboratory monitoring. ${ }^{2}$ Current guidelines indicate that initial ART should contain an NNRTI (either nevirapine-NVP or efavirenz-EFV) plus two NRTIs, one of which should be zidovudine (AZT) or tenofovir disoproxil fumarate (TDF) and the other lamivudine (3TC) or emtricitabine (FTC). ${ }^{2}$

Cost of the drug as well as the cost of monitoring the patients, management of adverse drug reactions, drug substitution and change of regimens also affects selection of a drug. Thus, comparing agents in terms of outcome during routine patient care is useful for policy makers regarding ART selection. ${ }^{3-5}$ Some studies have assessed survival, morbidity and medication adherence among Indian patients receiving ART in the private and nongovernmental sectors. ${ }^{3-5}$ This study examined treatment outcomes in terms of immunological improvement, improvement in weight and haemoglobin, occurrence of opportunistic infections and adverse reactions using routinely collected ART data from the tertiary care hospital setting. Further, a nonrandomized comparison study of TDF with other commonly used nucleoside reverse transcriptase inhibitors based regimens was undertaken.

\section{Objectives}

\section{Primary objective}

To assess the change in $\mathrm{CD}_{4}{ }^{+}$cell count following one year of antiretroviral therapy in treatment naïve HIV positive patients.

\section{Secondary objectives}

1. To study the one year outcome of antiretroviral therapy with respect to change in hemoglobin and weight in treatment naïve patients.

2. To assess and compare treatment outcome and adverse drug reaction (ADR) profile between patients ontenofovir versus those on non-tenofovir based antiretroviral regimen.

\section{METHODS}

A prospective cohort study was conducted from September, 2012 to August, 2014 at a tertiary care hospital in South India, after obtaining approval from Institutional Ethics committee. The study data was collected from the case records of patients in the HIV clinic and medical records department. HIV positive patients ( $>18$ years of age) who were treatment naive and started on antiretroviral therapy (ART) as per the national guidelines, between $1^{\text {st }}$ January 2011 and $31^{\text {st }}$ May 2013, were included in the study. The data related to one year follow up following start of ART was collected. Patients demographics, antiretroviral regimen initiated, drug substitution and change of regimen was noted. $\mathrm{CD}_{4}{ }^{+}$cell count, haemoglobin level, weight, occurrence of opportunistic infections (OIs) and adverse drug reactions (ADRs) were analysed at baseline, 6 and 12 months following start of antiretroviral therapy.

\section{Statistical analysis}

A descriptive approach was used for data analysis. The results were expressed as percentage. Changes in $\mathrm{CD}_{4}{ }^{+}$ cell count, haemoglobin level and weight were analysed in terms of the median change between baseline and follow-up measures at 6 and 12 months. Independent samples t-test was used to compare mean baseline values (age, weight and haemoglobin) between groups. MannWhitney $U$ test/two-sample Wilcoxon signed rank test was performed to compare medians of continuous variables between groups (change in haemoglobin, change in weight and change in $\mathrm{CD}_{4}{ }^{+}$count). Fisher's exact test was conducted to determine the significant difference between groups for count data (No. of patients with OIs/ADRs). $\mathrm{P}<0.05$ was considered statistically significant.

\section{RESULTS}

\section{Demographic profile}

Baseline demographic, clinical and immunological characteristics of 325 patients initiated on antiretroviral therapy (ART) has been illustrated in Table 1 .

\section{Treatment outcomes}

Change in weight and haemoglobin levels during follow up

Patients improved clinically with regard to weight and haemoglobin levels during the 1-year treatment period. At the end of 12 months, the median increase in haemoglobin was $1.5 \mathrm{~g} / \mathrm{dL}$ (IQR $0.7-2.5$ ) and the median weight gain was $3 \mathrm{~kg}$ (IQR 1-6, $\mathrm{n}=325$ ) (Table 2).

\section{$\mathrm{CD}_{4}{ }^{+}$changes during follow up}

The median increase in $\mathrm{CD}_{4}{ }^{+}$count at 1 year was 158 cells $/ \mathrm{mm}^{3}$ (IQR 124-205; $\mathrm{n}=154$ ) (Table 2). It increased 
by $50-100$ cells $/ \mathrm{mm}^{3}$ in $4(1.2 \%)$ patients and more than 100 cells $/ \mathrm{mm}^{3}$ in $150(46.2 \%)$ patients.

\section{ART regimens used}

The tenofovir (TDF) based regimens used were TDF (tenofovir)+3TC/FTC (lamivudine/emtricitabine) + EFV/NVP (efavirenz/nevirapine). The non-tenofovir based regimens used were AZT (zidovudine) + 3TC (lamivudine)+NVP/EFV (efavirenz/nevirapine); $\mathrm{d} 4 \mathrm{~T}$ (stavudine)+3TC (lamivudine) $+\mathrm{NVP} / \mathrm{EFV}$ (efavirenz/nevirapine) and ddl (didanosine)+3TC (lamivudine)+NVP (nevirapine) .

Table 1: Baseline demographic, clinical and immunological characteristics of 325 patients initiated on antiretroviral therapy.

\begin{tabular}{|ll|}
\hline Characteristics & \\
\hline Age in years & $\mathrm{n}(\%)$ \\
\hline $18-30$ & $29(8.9)$ \\
\hline $31-45$ & $144(44.3)$ \\
\hline$>45$ & $152(46.8)$ \\
\hline Employment & $\mathrm{n}(\%)$ \\
\hline Employed & $231(71)$ \\
\hline Gender & $\mathrm{n}(\%)$ \\
\hline Male & $232(71.4)$ \\
\hline Female & $93(28.6)$ \\
\hline Marital status & $\mathrm{n}(\%)$ \\
\hline Married & $292(89.8)$ \\
\hline Opportunistic Infections & $\mathrm{n}(\%)$ \\
\hline At least one before start of ART & $222(68.3)$ \\
\hline Weight $\left(\right.$ Mean \pm SD) $^{\text {Haemoglobin }(\text { Mean } \pm \text { SD) }}$ & $52.9 \pm 9.1 \mathrm{~kg}$ \\
\hline CD $_{4}^{+}$count (Median) [IQR] & $11.5 \pm 2 \mathrm{~g} / \mathrm{dl}$ \\
\hline
\end{tabular}

$\mathrm{n}=$ no. of patients; value in parentheses are percentages unless otherwise stated

\section{Occurrence of opportunistic infections (OI)}

During the 1-year treatment period, $11.1 \%$ of patients (36/325) had one or more OIs (Table 2). The frequency of OIs was highest in the initial months of treatment and declined sharply thereafter. The cumulative proportion of patients who reported an OI after start of treatment at 6 and 12 months was $8.9 \%$ and $11.1 \%$ respectively. After the start of treatment, mucosal candidiasis $(n=55 ; 16.9 \%)$ was the most common OI reported, followed by cryptococcal meningitis $(n=15 ; 4.6 \%)$. The others were pulmonary tuberculosis $(\mathrm{n}=14)$, Pneumocystis jiroveci pneumonia $(n=7)$, disseminated tuberculosis $(n=6)$ and TB lymphadenitis $(n=3)$.

\section{Adverse drug reactions (ADRs)}

During the 1-year treatment period, $40 \%$ of patients (130/325) reported ADRs (Table 2). Of a total of 151 side-effects reported, the most frequent were skin rash
(24\%), anaemia (17\%), gastrointestinal adverse effects (17\%), peripheral neuropathy, pancreatitis and renal failure ( $8 \%$ each). The occurrence of side-effects was not significantly associated with baseline weight.

Table 2: Treatment outcomes of 325 patients following initiation of antiretroviral therapy.

\begin{tabular}{|c|c|c|}
\hline Characteristics & At 6 months & At 12 months \\
\hline $\begin{array}{l}\text { Change in Hb } \\
\text { (Median) (IQR) }\end{array}$ & $\begin{array}{l}0.5(0.4-1.3) \\
\mathrm{g} / \mathrm{dL}\end{array}$ & $\begin{array}{l}1.5(0.7-2.5) \\
\mathrm{g} / \mathrm{dL}\end{array}$ \\
\hline $\begin{array}{l}\text { Change in weight } \\
\text { (Median) (IQR) }\end{array}$ & $1(0-4) \mathrm{kg}$ & $3(1-6) \mathrm{kg}$ \\
\hline $\begin{array}{l}\text { Change in } \mathrm{CD}_{4}^{+} \\
\text {count (Median) } \\
(\mathrm{IQR})^{*}\end{array}$ & $\begin{array}{l}90(63-128) \\
\text { cells } / \mathrm{mm}^{3}\end{array}$ & $\begin{array}{l}158(124-205) \\
\text { cells } / \mathrm{mm}^{3}\end{array}$ \\
\hline $\begin{array}{l}\text { No. of patients with } \\
\text { ADR } n(\%)\end{array}$ & - & $130(40 \%)$ \\
\hline $\begin{array}{l}\text { No. of patients with } \\
\text { treatment } \\
\text { substitution } \\
\mathrm{n}(\%)\end{array}$ & $50(15.4 \%)$ & $90(27.7 \%)$ \\
\hline $\begin{array}{l}\text { No. of patients with } \\
\text { OIs after start of } \\
\text { ART } n(\%)\end{array}$ & $29(8.9 \%)$ & $36(11.1 \%)$ \\
\hline $\begin{array}{l}\text { No. of patients loss } \\
\text { to follow up n }(\%)\end{array}$ & - & $24(7.4 \%)$ \\
\hline $\begin{array}{l}\text { Cumulative no. of } \\
\text { patients died n }(\%)\end{array}$ & $1(0.3 \%)$ & $4(1.2 \%)$ \\
\hline
\end{tabular}

$*_{n}=154$; patients with missing values, those died, loss to follow up, treatment failure cases confirmed by HIV RNA load and those who stopped drugs either due to side-effects or missed to take were excluded from analysis.

\section{Regimen}

Thirty-five per cent of patients were started on AZT $+3 \mathrm{TC}+\mathrm{NVP}$ while $31 \%$ started on TDF+FTC+EFV. Among 90 of the 325 patients, one of the drugs in the regimen had to be substituted during the 1-year treatment period (Table 2).

\section{Loss to follow-up and mortality}

Of the 325 adults started on ART, treatment outcomes were available for 301 patients over 1 year; of these, 297 patients were alive after 1 year of treatment. The cumulative loss to follow-up at 12 months after ART initiation was $7.4 \%$ (24/325) (Table 2). Overall, 4 (1.2\%) of the 325 patients died during one year. Over the 1-year period, in $57(17.5 \%)$ patients the prescribed monthly drugs were either stopped due to side-effects or the patient failed to take the drugs on at least 1 occasion. Adherence to treatment was reported in 229 (70.2\%) patients. Treatment failure was confirmed by HIV RNA load test in $11(3.4 \%)$ patients at the end of 1 year. In this study, data regarding HIV RNA was not included for analysis (except in 11 patients to confirm treatment 
failure), as majority of patients refused to take the test due to cost involved in testing.

\section{Comparison of patients on tenofovir based versus those on non-tenofovir based regimens}

Comparison of baseline characteristics between two groups

There was no significant difference in baseline characteristics between the two groups (Table 3).

Table 3: Comparison of demographic and baseline characteristics between tenofovir and non-tenofovir based regimens.

\begin{tabular}{|c|c|c|c|}
\hline Characteristics & $\begin{array}{l}\text { Tenofovir } \\
\text { based } \\
\text { regimen }\end{array}$ & $\begin{array}{l}\text { Non- } \\
\text { tenofovir } \\
\text { based } \\
\text { regimen }\end{array}$ & \\
\hline No. of patients & $143(44 \%)$ & $182(56 \%)$ & \\
\hline $\begin{array}{l}\text { Sex } \\
\text { Male } \\
\text { Female }\end{array}$ & $\begin{array}{l}108(75.5 \%) \\
35(24.5 \%)\end{array}$ & $\begin{array}{l}124(68.1 \%) \\
58(31.9 \%)\end{array}$ & \\
\hline Age (Mean + SD) & $44 \pm 11$ years & $47 \pm 12$ years & \\
\hline $\begin{array}{l}\text { Weight } \\
\text { (Mean+SD) }\end{array}$ & $\begin{array}{l}52.3 \pm 8.9 \\
\mathrm{~kg}\end{array}$ & $\begin{array}{l}53.43 \pm 9.2 \\
\mathrm{~kg}\end{array}$ & $\begin{array}{l}P= \\
0.270 *\end{array}$ \\
\hline $\begin{array}{l}\text { Haemoglobin } \\
(\text { Mean +SD) }\end{array}$ & $\begin{array}{l}11.27 \pm 2.1 \\
\mathrm{~g} / \mathrm{dL}\end{array}$ & $\begin{array}{l}11.6 \pm 1.8 \\
\mathrm{~g} / \mathrm{dL}\end{array}$ & $\begin{array}{l}P= \\
0.139 *\end{array}$ \\
\hline $\begin{array}{l}\mathrm{CD}^{+} \text {count } \\
(\text { Median })(\mathrm{IQR})\end{array}$ & $\begin{array}{l}85 \\
(43-250) \\
\text { cells } / \mathrm{mm}^{3}\end{array}$ & $\begin{array}{l}113 \\
(61-231) \\
\text { cells } / \mathrm{mm}^{3}\end{array}$ & $\begin{array}{l}\mathrm{P}= \\
0.754 * *\end{array}$ \\
\hline $\begin{array}{l}\text { No. with } \\
\text { opportunistic } \\
\text { infection before } \\
\text { start of ART n } \\
(\%)\end{array}$ & $\begin{array}{l}104 \\
(72.7 \%)\end{array}$ & $\begin{array}{l}118 \\
(64.8 \%)\end{array}$ & \\
\hline
\end{tabular}

*Independent samples t-test, **Mann Whitney $\mathrm{U}$ test, $\mathrm{n}=$ number of patients

\section{Comparison of treatment outcomes between two groups}

There was no significant difference in median change in weight and haemoglobin between the two groups. Neurological side-effects were most commonly reported by patients started on a stavudine (d4T)-based regimen $(11,7 \%)$, anaemia by those on AZT-based regimen (24, $16 \%)$ and renal failure in $(12,8 \%)$ patients on tenofovir based regimens. Patients on tenofovir based regimen were less likely to develop an adverse drug reaction (ADR) and experience an OI than those on non-tenofovir based regimen (Table 4). The commonly used nontenofovir based regimen was AZT+3TC+NVP. Of the 114 patients started on $\mathrm{AZT}+3 \mathrm{TC}+\mathrm{NVP}$, the regimen was changed to $\mathrm{TDF}+3 \mathrm{TC}+\mathrm{EFV}$ in $12(34 \%)$ and to $\mathrm{AZT}+3 \mathrm{TC}+\mathrm{EFV}$ in $11(31 \%)$. The commonly used tenofovir based regimen (100 patients) was $\mathrm{TDF}+\mathrm{FTC}+\mathrm{EFV}$ which was changed to $\mathrm{AZT}+3 \mathrm{TC}+\mathrm{NVP}$ in 8 of them.
Table 4: Comparison of treatment outcomes at the end of 1 year between tenofovir and non-tenofovir based regimens (total number of patients $=325$ ).

\begin{tabular}{|c|c|c|c|}
\hline Characteristics & $\begin{array}{l}\text { Tenofovir } \\
\text { based } \\
\text { regimen } \\
(\mathrm{n}=143)\end{array}$ & $\begin{array}{l}\text { Non- } \\
\text { tenofovir } \\
\text { based } \\
\text { regimen } \\
(\mathrm{n}=182)\end{array}$ & \\
\hline $\begin{array}{l}\text { Change in } \mathrm{Hb} \\
\text { (Median) } \\
\text { (IQR) }\end{array}$ & $\begin{array}{l}1.8 \\
(1-2.7) \\
\mathrm{g} / \mathrm{dL}\end{array}$ & $\begin{array}{l}1.2 \\
(0.6-2.1) \\
\mathrm{g} / \mathrm{dL}\end{array}$ & \\
\hline $\begin{array}{l}\text { Change in } \\
\text { weight } \\
\text { (Median) } \\
\text { (IQR) }\end{array}$ & $\begin{array}{l}4 \\
(1-6) \mathrm{kg}\end{array}$ & $\begin{array}{l}3.4 \\
(1-6) \mathrm{kg}\end{array}$ & $\mathrm{P}=0.825^{* *}$ \\
\hline $\begin{array}{l}\text { Change in } \\
\mathrm{CD}_{4}^{+} \\
\text {count(Median) } \\
(\mathrm{IQR})^{*}\end{array}$ & $\begin{array}{l}175 \\
(136-205) \\
\text { cells } / \mathrm{mm}^{3}\end{array}$ & $\begin{array}{l}144 \\
(115-211) \\
\text { cells } / \mathrm{mm}^{3}\end{array}$ & $\begin{array}{l}\mathrm{P}= \\
1.12 \times 10^{-5} * *\end{array}$ \\
\hline $\begin{array}{l}\text { Patients with } \\
\text { ADR } \\
\text { Patients } \\
\text { without ADR }\end{array}$ & $\begin{array}{l}33(23.1 \%) \\
110(33.8 \%)\end{array}$ & $\begin{array}{l}97(53.3 \%) \\
85(26.2 \%)\end{array}$ & $\begin{array}{l}\mathrm{OR}=0.26 \\
\mathrm{P}= \\
3.35 \times 10^{-08} * * *\end{array}$ \\
\hline $\begin{array}{l}\text { Regimen } \\
\text { frequently } \\
\text { used for } \\
\text { substitution }\end{array}$ & $\begin{array}{l}\mathrm{AZT}+3 \mathrm{TC} \\
+\mathrm{NVP} \\
8(5.6 \%)\end{array}$ & $\begin{array}{l}\text { TDF+FTC } \\
+\mathrm{EFV} \\
20(11 \%)\end{array}$ & \\
\hline $\begin{array}{l}\text { No. of patients } \\
\text { with OIs after } \\
\text { start of ART }\end{array}$ & $\begin{array}{l}10 \\
(7 \%)\end{array}$ & $\begin{array}{l}26 \\
(14.3 \%)\end{array}$ & $\begin{array}{l}\mathrm{OR}=0.99 \\
\mathrm{P}=1 * * *\end{array}$ \\
\hline $\begin{array}{l}\text { No. of patients } \\
\text { loss to follow } \\
\text { up }\end{array}$ & $8(5.6 \%)$ & $16(8.8 \%)$ & \\
\hline $\begin{array}{l}\text { No. of patients } \\
\text { died }\end{array}$ & $1(0.7 \%)$ & $3(1.7 \%)$ & \\
\hline
\end{tabular}

$*^{*}=154$; patients with missing values, those died, loss to follow up, treatment failure cases confirmed by HIV RNA load and those who stopped drugs either due to side-effects or missed to take were excluded from analysis **Two-sample Wilcoxon signed rank test; ***Fisher's exact test

\section{DISCUSSION}

A majority of patients were above 45 years of age and the proportion of males was more than two-fold greater than the females. This is consistent with another study in Indian scenario wherein there was a predominance of males. ${ }^{16}$ This study data showed that women had a higher median $\mathrm{CD}_{4}{ }^{+}$cell count at baseline. This was because most of them who had acquired the infection from their HIV- positive spouse were diagnosed before any symptom manifestation.

Almost half of the patients presented late for treatment with poor baseline parameters such as baseline $\mathrm{CD}_{4}^{+}$ count less than 100 cells $/ \mathrm{mm}^{3}$ and presence of opportunistic infections. This finding points to the need for rapid scale-up of counselling and testing for early detection of asymptomatic cases in developing countries. 
This study is also consistent with the results of Boltonmore et al, that patients starting a zidovudine-based regimen or nevirapine-based regimen were considerably more likely over time to have that drug substituted, compared with patients starting a tenofovir-based regimen or efavirenz-based regimen respectively. ${ }^{11,13}$ It was observed that the NACO recommended first-line regimens are fairly well tolerated and associated with adherence rates comparable with those in the United States. ${ }^{17}$

Almost fifty per cent of the patients in the cohort experienced a more than doubling of his or her $\mathrm{CD}_{4}{ }^{+}$cell count in the first 12 months of ART. The $\mathrm{CD}_{4}^{+}$cell response is generally vigorous for treatment naïve patients on ART. Here in this study, $\mathrm{CD}_{4}{ }^{+}$lymphocyte count gains were impressive and are similar in magnitude at 1 year on treatment to those reported elsewhere, in spite of the relatively late initiation of treatment. ${ }^{14,18,19}$

New pulmonary infections occurring while patients are receiving ART are well diagnosed in this setting. The study also showed a gradual decline in the presence of OIs following ART. New reports of OI during the followup period reduced with treatment.

Definitive evidence regarding the relative efficacy of various treatment strategies can only be gathered through randomized clinical trials. Information about the same in controlled conditions in different patient population should be obtained to check if results are similar. The findings in our study shows the effect of the introduction of tenofovir based regimens as first-line regimen by the treating physician as established in clinical trials. ${ }^{7,10}$ This effect was maintained when subgroup analyses comparing tenofovir and non-tenofovir based regimens was performed. The comparison was done based on the baseline characteristics and treatment outcomes between the two groups. This was possible as the vast majority of subjects in the study received initial therapy with a regimen containing either tenofovir or zidovudine.

Rate of treatment change due to adverse events were uniformly low, and comparable or lower than those published for other cohorts. ${ }^{9,20}$ This demonstrates that with standardized regimens, and monitoring, ART can be safely used in resource-constrained settings. The most common indication resulting in a treatment change was in patients who developed tuberculosis after starting ART and who were switched from nevirapine to efavirenz, due to concerns about the co-administration of nevirapine with rifampicin.

Unlike other published reports, here only four deaths were found during one year follow-up of patients. ${ }^{7,15,21,22}$ Though the specific cause of death could not be ascertained, it was found that three of them had a baseline $\mathrm{CD}_{4}{ }^{+}$count of less than 100 cells $/ \mathrm{mm}^{3}$. Mortality could be further avoided by monitoring those with advanced disease as they start ART, and it raises the possibility that early mortality could also be due to undiagnosed opportunistic infections, nutritional deficiencies, or severe immune reconstitution inflammatory syndrome, although there is no direct evidence to support these possible reasons. $^{23-25}$

This study showed reduced early mortality as patients who attended the clinic were diagnosed quickly and were counselled to start ART before they become wasted and anemic. ${ }^{6}$ Though the stigma associated with the disease prevent patients from seeking early treatment, the free provision of drugs by government ART centres has encouraged people to seek medical attention earlier, as has been observed in the United States and other developed countries. ${ }^{8}$

Adherence to medication and lifestyle changes is a key factor to positive treatment outcome in the therapy of HIV/AIDS and this presents a challenge to both patients and healthcare providers. ${ }^{12,26-30}$ Our patients were counselled on the basic facts about ART before and after treatment initiation.

Despite these and the fact that all the respondents were counselled on medication adherence before starting ART, adherence was still found to be poor, $70.2 \%$ (229), compared to the $100 \%$ recommended level of adherence required to achieve the goal of ART. The data was collected from case records as reported by patients. This is consistent with a recent study of self-reported poor adherence $(<80 \%){ }^{20}$ The various reasons for nonadherence could be busy working schedule, pill burden, cost, lack of understanding of how to take drugs, etc.

Although this study has not sought to explore the costs of treatment, HIV RNA testing is expensive relative to drug costs. This highlights the need for lower cost of HIV RNA testing together with antiretroviral drugs, or of validating approaches that do not include HIV RNA testing.

Strengths of this study include the intent-to-treat analysis, and complete follow-up for $93 \%$ of the cohort.

The principal limitation of the analysis is the short duration of follow-up and the small numbers at risk in the analysis of those on 1 year of treatment. The results of this study are, however, comparable with data from observational settings in both developed and developing countries. This study builds on results reported for other Indian settings in demonstrating the feasibility of successful ART centres in these contexts. ${ }^{31-34}$

As this was an observational study, there wasn't a control group and hence treatment outcome for every patient was assessed by comparing the pre-ART $\mathrm{CD}_{4}{ }^{+}$cells counts and $\mathrm{CD}_{4}{ }^{+}$cells counts while on ART. Fluctuations in absolute $\mathrm{CD}_{4}{ }^{+}$count do occur requiring repeated measurements to make a definite conclusion, but that was not the case with this study. ${ }^{35}$ The actual causes of death 
could also not be ascertained. There were cases of missing or incomplete records with regard to recording of sideeffects and follow up measurements of clinical and immunological parameters that hampered the study. Some aspects of data collection were based on self-report, which could be biased. Thus, the frequency of side-effects reported may be underestimated and the reported clinical and immunological improvements may be biased towards a higher value.

The results remained statistically significant after adjusting for presence of $\mathrm{OI}, \mathrm{CD}_{4}{ }^{+}$cell count, sex, and age at baseline. These findings provide encouragement to physicians seeking to provide similar services in poor communities where HIV morbidity and mortality are high.

\section{CONCLUSION}

By following the current national guidelines, the immunological and clinical outcome of ART while minimizing adverse drug reactions during the first year of treatment, did not differ from those in developed countries.

\section{Funding: No funding sources}

Conflict of interest: None declared

Ethical approval: The study was approved by the Institutional Ethics Committee

\section{REFERENCES}

1. National Aids Control Organisation. ART guidelines for HIV-Infected Adults and Adolescents including Post-exposure prophylaxis. New Delhi: NACO; 2013. Available at, http://www.naco.gov.in/upload/Policies\% 20\&\%20Guidelines/Antiretroviral\%20Therapy\%20 Guidelines\%20for\%20HIV Infected\%20Adults\%20and\%20Adolescents.pdf. Accessed on 25 August, 2014.

2. Safrin S. Antiviral agents. In: Katzung BG, Masters SB, Trevor AJ, editors. Basic and Clinical Pharmacology. $11^{\text {th }}$ edition. New Delhi: Tata McGraw Hill companies; 2009:856.

3. Bachani D, Garg R, Rewari BB, Hegg L, Rajasekaran S, Deshpande A, et al. Two-year treatment outcomes of patients enrolled in India's national first-line antiretroviral therapy programme. Natl Med J India. 2010;23:7-12.

4. Shah B, Walshe L, Saple DG, Mehta SH, Ramnani JP, Kharkar R, et al. Adherence to antiretroviral therapy and virologic suppression among HIVinfected persons receiving care in private clinics in Mumbai, India. Clin Infect Dis. 2007;44(9):1235-44.

5. Kumarasamy N, Safren SA, Raminani SR, Pickard R, James R, Krishnan AS, et al. Barriers and facilitators to antiretroviral medication adherence among patients with HIV in Chennai, India: a qualitative study. AIDS patient care STDs. 2005;19(8):526-37.

6. Cornett JK, Kirn TJ. Laboratory diagnosis of HIV in adults: a review of current methods. Clin Infect Dis 2013;57:712.

7. Grinsztejn B, Hosseinipour MC, Ribaudo HJ, Swindells S, Eron J, Chen YQ, et al. Effects of early versus delayed initiation of antiretroviral treatment on clinical outcomes of HIV-1 infection: results from the phase 3 HPTN 052 randomised controlled trial. Lancet Infect Dis. 2014;14:281.

8. Joint United Nations Programme on HIV/AIDS. UNAIDS Report on the Global AIDS Epidemic, 2013. Geneva: UNAIDS; 2013. Available at, http://www.unaids.org/en/resources/documents/2013 /name, 85053.pdf. Accessed on 25 August 2014.

9. ART-LINC of IeDEA Study Group, Keiser O, Tweya H, Boulle A, Braitstein P, Schecter M, Brinkhof MW, et al. Switching to second-line antiretroviral therapy in resource-limited settings: comparison of programmes with and without viral load monitoring. AIDS. 2009;23:1867.

10. Thompson MA, Aberg JA, Hoy JF, Telenti A, Benson C, Cahn P, et al. Antiretroviral treatment of adult HIV infection: 2012 recommendations of the International Antiviral Society-USA panel. JAMA 2012;308:387.

11. Deeks SG, Wrin T, Liegler T, Hoh R, Hayden M, Barbour JD, et al. Virologic and immunologic consequences of discontinuing combination antiretroviral-drug therapy in HIV-infected patients with detectable viremia. $\mathrm{N}$ Engl $\mathrm{J}$ Med. 2001;344:472.

12. Osterberg L, Blaschke T. Adherence to medication. N Engl J Med. 2005;353:487.

13. Bolton-Moore C, Mubiana-Mbewe M, Cantrell RA, Chintu N, Stringer EM, Chi BH. Clinical outcomes and $\mathrm{CD}_{4}{ }^{-}$cell response in children receiving antiretroviral therapy at primary health care facilities in Zambia. JAMA. 2007;298(16):1888-99.

14. Grabar S, Le Moing V, Goujard C, Leport C, Kazatchkine MD, Costagliola D, et al. Clinical outcome of patients with HIV-1 infection according to immunologic and virologic response after 6 months of highly active antiretroviral therapy. Ann Intern Med. 2000;133:401-10.

15. Coetzee D, Hildebrand K, Boulle A, Maartens G, Louis F, Labatala V, et al. Outcomes after two years of providing antiretroviral treatment in Khayelitsha, South Africa. AIDS 2004;18:887-95.

16. Hira SK, Dupont HL, Lanjewar DN, Dholakia YN. Severe weight loss: the predominant clinical presentation of tuberculosis in patients with HIV infection in India. Natl Med J India. 1998;11:256-8.

17. Grossberg R, Zhang Y, Gross R. A time-toprescription-refill measure of antiretroviral adherence predicted changes in viral load in HIV. J Clin Epidemiol. 2004;57:1107-10.

18. Smith CJ, Sabin CA, Lampe FC, Kinloch-de-Loes S, Gumley $\mathrm{H}$, Carroll A, et al. The potential for $\mathrm{CD}_{4}$ 
cell increases in HIV-positive individuals who control viraemia with highly active antiretroviral therapy. AIDS. 2003;17:963-9.

19. Mocroft A, Madge S, Johnson AM, Lazzarin A, Clumeck N, Goebel FD, et al. A comparison of exposure groups in the EuroSIDA study: starting highly active antiretroviral therapy (HAART), response to HAART, and survival. J Acquir Immune Defic Syndr. 1999;22:369-78.

20. d'Arminio MA, Lepri AC, Rezza G, Pezzotti P, Antinori A, Phillips AN, et al. Insights into the reasons for discontinuation of the first highly active antiretroviral therapy (HAART) regimen in a cohort of antiretroviral naive patients. I.CO.N.A. Study Group. Italian Cohort of Antiretroviral-Naive Patients. AIDS. 2000;14:499-507.

21. Weidle PJ, Malamba S, Mwebaze R, Sozi C, Rukundo G, Downing R, et al. Assessment of a pilot antiretroviral drug therapy programme in Uganda: patients' response, survival, and drug resistance. Lancet. 2002;360:34-40.

22. Antiretroviral Therapy in Lower Income Countries (ART-LINC) Collaboration and ART Cohort Collaboration (ART-CC) groups. Mortality of HIV1-infected patients in the first year of antiretroviral therapy: comparison between low-income and highincome countries. Lancet. 2006;367:817-24.

23. Anabwani G, Navario P. Nutrition and HIV/AIDS in sub-Saharan Africa: an overview. Nutrition 2005;21:96-9.

24. Mayo J, Collazos J, Martinez E, Ibarra S. Adrenal function in the human immunodeficiency virusinfected patient. Arch Intern Med. 2002;162:1095-8.

25. DeSimone JA, Pomerantz RJ, Babinchak TJ. Inflammatory reactions in HIV-1-infected persons after initiation of highly active antiretroviral therapy. Ann Intern Med. 2000;133:447-54.

26. Praska JL, Kripalani S, Seright AL, Jacobsen TA. Identifying and assisting low-literacy patients with medication use: a survey of community pharmacies. Ann Pharmacother. 2005;39:1441-5.

27. Vanhove GF, Schapiro JM, Winters MA. Patient compliance and drug failure in protease inhibitor monotherapy. JAMA. 1996;276:1955-6.
28. Deeks S, Beatty G, Cohen PT. Viral load and $\mathrm{CD}_{4}{ }^{+}$ T-cell changes in patients failing potent protease inhibitor therapy. Abstract 419. In: Program and abstracts of the $5^{\text {th }}$ Conference on Retroviruses and Opportunistic Infections; Chicago, United States; 1998.

29. Montaner JS, Reiss P, Cooper D. A randomized, double-blind trial comparing combinations of nevirapine, didanosine, and zidovudine for HIVinfected patients: the INCAS Trial. Italy, the Netherlands, Canada, and Australia Study. JAMA. 1998;279:930-7.

30. Melbourne KM., Geletko SM, Brown SL, WilleyLessne C, Chase S, Fisher A. Medication Adherence in Patients with HIV Infection: a comparison of two measurement methods. AIDS. 1999;9(5):329-38.

31. Corey DM, Kim HW, Salazar R, Illescas R, Villena J, Gutierrez L, et al. Brief report: effectiveness of combination antiretroviral therapy on survival and opportunistic infections in a developing world setting: an observational cohort study. J Acquir Immune Defic Syndr. 2007;44(4):451-5.

32. Kumarasamy N, Solomon S, Chaguturu SK, Mahajan AP, Flanigan TP, Balakrishnan P, et al. The safety, tolerability and effectiveness of generic antiretroviral drug regimens for HIV-infected patients in south India. AIDS. 2003;17(15):2267-9.

33. Pujari SN, Patel AK, Naik E, Patel KK, Dravid A, Patel JK, et al. Effectiveness of generic fixed-dose combinations of highly active antiretroviral therapy for treatment of HIV infection in India. J Acquir Immune Defic Syndr. 2004;37(5):1566-9.

34. Pujari S, Dravid A, Gupte N, Joshix K, Bele V. Effectiveness and safety of generic fixed-dose combination of tenofovir/emtricitabine/efavirenz in HIV-1-infected patients in Western India. J Int AIDS Soc. 2008;10(8):196.

35. Palella FJ, Deloria-Knoll M, Chmiel JS. Survival benefit of initiating antiretroviral therapy in HIV infected persons in different $\mathrm{CD}_{4}{ }^{+}$cell strata. Ann Intern Med. 2003;138(8):620-6.

Cite this article as: Manohar HD, Shenoy S,

Varma M, Kamath A, Malalur C, Bairy KL, et al. Antiretroviral therapy outcome in human immunodeficiency virus infected patients in a tertiary care hospital. Int J Basic Clin Pharmacol 2016;5:616-22. 